\title{
WISATA BUATAN DI MERUYUNG SEBAGAI LOKASI PEMBELAJARAN BERWIRAUSAHA BERDASARKAN PERSEPSI MASYARAKAT
}

\author{
Siti Marti'ah ${ }^{1}$, Berta Dian Theodora ${ }^{2}$ \\ ${ }^{1)}$ Program Studi Informatika, Universitas Indraprasta PGRI \\ 1) Email: martia_setiadi@yahoo.co.id \\ ${ }^{2}$ Program Studi Informatika, Universitas Indraprasta PGRI \\ ${ }^{2)}$ Email: Berta.dtos@gmail.com
}

\begin{abstract}
Abstrak
Pengembangan objek wisata di kota Depok tidak hanya terbatas pada objek wisata alam dan sejarah, namun terdapat pula banyak objek wisata buatan. Masjid kubah emas selain digunakan sebagai tempat ibadah, pengunjung dan masyarakat mengunakannnya sebagai tempat berwisata religi. Animo keingintahuan terhadap masjid yang berlapis emas ini sangat tinggi, destinasi wisata religi merupakan salah satu tempat favourit warga depok ataupun jabodetabek. Penelitian bertujuan untuk mengidentifikasi konsep partisipasi masyarakat dalam pengembangan pariwisata buatan di kelurahan meruyung (2) mengidentifikasi konsep pengembangan pariwisata di meruyung dan dampaknya terhadap kehidupan ekonomi masyarakat. Metode penelitian menggunakan pendekatan kualitatif. Pemilihan sampel menggunakan snowball sampling dimana lurah meruyung menjadi sumber utama. Keberadaan masjid sebagai lokasi wisata religi merupakan nilai tambah yang dapat dirasakan oleh pengunjung ketika mengunjunginya. Sebagai sebuah lokasi wisata para wisatawan datang dengan alasan yang berbeda diantaranya 1) ingin melihat langsung masjid dengan kubah yang berlapis emas 2) niat beribadah, 3) berwisata ,4) melihat arsitektur masjid. Pengunjung dan masyarakat setuju untuk mengatakan masjid kubah emas sebagai tempat wisata terlihat dari persentase jawaban bahwa $98 \%$ (18\% sangat setuju dan $80 \%$ setuju) masyarakat setuju sebagai tembat berwisata, dan $97 \%$ (12\% sangat setuju dan $85 \%$ setuju) masyarakat setuju telah merasakan keberadaan masjid kubah emas sebagai tempat untuk mendapatkan penghasilan. Hasil kuesioner yang diberikan kepada pedagang lokal mengenai kesempatan yang diberikan pihak pengelola kepada pedagang lokal untuk dapat berjualan dikawasan masjid kubah emas.
\end{abstract}

Kata Kunci : Wisata Buatan, Meruyung, pembelajaran berwirausaha

\begin{abstract}
The tourist attractions developed in Depok are not only nature and heritage tourism, but also artificial tourism. For example, Mosque of golden dome (masjid kubah emas) is used not just for place or worship, but it is also used by visitors as a religious tourism. The visitors' great curiosity about this mosque makes it one of favorite tourism destinations of people in Depok and Jabodetabek. The research is aimed at identifying the concept of community participation in the development of artificial tourism in Meruyung subdistrict (2) the concept of tourism development in Meruyung and its effects on economic life of surrounding community. The research applies a qualitative approach. The samples are taken using snowball sampling, in which the subdistrict head of Meruyung becomes the main resource person. The existence of the mosque as a religious tourism is an added value that can be experienced by visitors during their visit. Many visitors come with different reasons such as 1) to direcly see the mosque with a gold-plated dome 2) to perform prayer, 3) to sightsee, 4) to see the mosque architecture. Visitors and community agree to call the mosque of golden dome a tourist site, as seen in the percentage of answers showing that $98 \%$ (18\% strongly agree and $80 \%$ agree) of the community agrees to call it a tourist site, and $97 \%$ (12\% strongly agree and $85 \%$ agree) of the community agrees to have made this mosque a place to earn income, as seen from the result of questionnaires distributed to local vendors showing
\end{abstract}


that they are given opportunity by local vendor management to sell things in the area of the mosque of golden dome.

Keywords : Artificial tourism, Meruyung, learning entrepreneurship

\section{Pendahuluan}

Dalam undang-undang No 10 tahun 2009 tentang kepariwisataan, wisata di definisikan sebagai kegiatan perjalanan yang dilakukan oleh seseorang atau sekelompok orang dengan mengunjungi tempat tertentu untuk rekreasi, pengembangan diri, atau mempelajari keunikan daya tarik wisata yang di kunjungi dalam jangka waktu sementara. Lebih lanjut, pengertian pariwisata adalah berbagai macam kegiatan wisata, atau bisa juga dikatakan berbagai macam perjalanan wisata dan di dukung sebagai fasilitas serta layanan yang disediakan oleh masyarakat, pengusaha, pemerintah, dan pemerintah daerah. Kebijakan pengembangan sektor pariwisatadijalankan bersama antar pemerintah pusat dan pemerintah daerah serta diarahkan guna menjadi sektor andalan dan unggulan dibeberapa kota. Pengembangan wisata dalam arti luas mampu menjadi salah satu penghasil devisa, mendorong ekonomi, meningkatkan pendapatan daerah, memberdayakan perekonomian rakyat dalam bentuk memperluas lapangan pekerjaan, dan kesempatan berusaha serta meningkatkan kesejahteraan rakyat dengan memelihara kepribadian bangsa, nilai-nilai agama serta kelestarian fungsi dan mutu lingkungan hidup. Kota Depokmempunyai tempat wisata buatan diantaranya kampung 99 dan masjid kubah emas yang berada dikecamatan limo, tamanbunga wiladatika dicibubur, Margocity dan Depok Town Square di kawasan Margonda.

Pengembangan objek wisata di kota Depok tidak hanya terbatas pada objek wisata alam dan sejarah, namun sekarang telah banyak objek wisata yang bersifat religi dan wisata keluarga. Masjid kubah emas selain digunakan sebagai tempat ibadah pengunjung dan masyarakat setempat mengunakannnya sebagai lokasi wisata religi. Animo keingintahuan masyarakat terhadap masjid yang berlapis emas ini sangat tinggi. Destinasi wisata ini merupakan tempat favourit warga Depok ataupun jabodetabek, tujuannya untuk beribadah dan berwisata religi.

Dengan berkembangnya jenis objek wisata religi yang awalnya merupakan sarana mendekatkan diri kepada sang pencipta, karena banyak dikunjungi oleh wisatawan maka sarana ibadah mengalami pergeseran makna menjadi industri pariwisata, bukannya hanya merupakan tempat beribadah namun menjadi kegiatan liburan semata sebagai pengisi waktu luang.

Keberadaan wisata buatan yang terus bermunculan seperti bangunan masjid kubah emas yang dimiliki secara pribadi, oleh ibu Dian Al-Mahri dan di kelola oleh Yayasan Dian AlMahri, memiliki dampak bagi masyarakat yang dirasakan langsung oleh masyarakat sekitar, pengunjung dan pedagang secara ekonomi atas keberadaan objek wisata tersebut. bermuara dari pendahuluan, penulis tertarik untuk membuat sebuah penelitian dengan judul "wisata buatan di meruyung sebagai lokasi pembelajaran berwirausaha"

Tujuan penelitian ini adalah untuk mengidentifikasi konsep partisipasi masyarakat dalam pengembangan pariwisata buatan di kelurahan meruyung serta mengidentifikasi konsep pengembangan pariwisata di meruyung dan dampaknya terhadap kehidupan ekonomi masyarakat. Sedangkan manfaat dari penelitian ini diharapkan dengan adanya pariwisata buatan tersebut masyarakata dapat mengambil peluang yang ada dengan membuat sebuah industri kreatif dengan memanfaatkan peluang wisata tersebut.

\section{Tinjauan Pustaka}

Persepsi Maryarakat

Persepsi bertautan dengan cara mendapatkan pengetahuan khusus tentang kejadian pada saat tertentu, maka persepsi dapat terjadi kapan saja apabila ada stimulus yang menggerakkan 
indera. Dalam hal ini persepsi diartikan sebagai proses mengetahui atau mengenali obyek dan kejadian obyektif dengan bantuan indera (Chaplin, C.P., 1999 : 358).

Suherman (2005 : 23) mengutip pendapat uttin dan Solso, mengemukakan, bahwa "persepsi merupakan tahap awal dari serangkaian pemrosesan informasi". Persepsi adalah suatu proses penggunaan pengetahuan atau memperoleh dan penginterpretasikan stimulus (rangsangan) yang diterima oleh alat indera manusia. Berdasarkan pemahaman tersebut persepsi merupakan proses menginterpretasikan atau menafsirkan informasi yang diperoleh melalui siste alat indera manusia, yang mencakup dua proses yang berlangsung secara serempak antara keterlibatan aspek-aspek dunia luar (stimulus-informasi/pengalaman) dengan dunia di dalam diri seseorang (pengetahuan yang relevan dan telah disimpan dalam ingatan).

Persepsi adalah suatu proses aktivitas seseorang dalam memberikan kesan, penilaian, pendapat, merasakan, dan menginterpretasikan sesuatu berdasarkan informasi yang ditampilkan dari sumber lain (yang dipersepsi). Melalui persepsi kita dapat mengenali dunia sekitar kita, yaitu seluruh dunia yang terdiri dari benda serta manusi dengan segala kejadiankejadiannya. Dengan persepsi pula kita dapat berinteraksi dengan dunia sekeliling kita, baik dengan sesama manusia, maupun dengan semua unsur yang ada di lingkungan sekitar kita.

Berdasarkan pengertian di atas disimpulkan bahwa persepsi adalah suatu proses yang kompleks dimana individu menerima dan menyadap informasi dari lingkungannya, menginderakan atau mengorganisasikan dan menginterpretasikan suatu obyek, dengan adanya keterlibatan aspek-aspek dunia luar (stimulus-informasi/pengalaman) dengan dunia di dalam diri seseorang (pengetahuan yang relevan dan telah disimpan dalam ingatan) sehingga mampu memahami dan memberikan penilaian terhadap obyek yang ada dihadapannya.

\section{Pariwisata}

Pariwisata merupakan aktivitas, pelayanan dan produk hasil industri pariwisata yang mampu menciptakan pengalaman dan perjalanan bagi wisatawan. Pengertian pariwisata menurut McIntosh ( $1995: 10$ ), pariwisata adalah " a composite of activities, services and idustries that deliver a travel experience: transportation, accomodation, eating and drinking establishment, shops, entertainment, activity, and other hospitality service available for individuals or group that are away from home". Pengertian pariwisata menurut UndangUndang Nomor 10 tahun 2009, pariwisata adalah berbagai macam kegiatan wisata dan didukung berbagai fasilitas serta layanan yang disediakan oleh masyarakat, pengusaha, pemerintah dan pemerintah daerah.

Pengertian pariwisata menurut WTO ( World Tourism Organization ) adalah berbagai aktivitas yang dilakukan oleh orang-orang yang mengadakan perjalanan untuk dan tinggal di luar kebiasaan lingkungannya dan tidak lebih dari satu tahun berturut-turut untuk kesenangan, bisnis, dan keperluan lain.Produk wisata merupakan sesuatu yang dapat ditawarkan kepada wisatawan untuk mengunjungi sebuah daerah tujuan wisata. Produk wisata dapat berupa alam, budaya serta hasil kerajinan masyarakat. Ada beberapa pendapat yang dikemukan oleh para ahli terhadap pengertian produk pariwisata, diantaranya :Menurut Gooddall (1991: 63), produk wisata dimulai dari ketersediaan sumber yang berwujud (tangible) hingga tak berwujud (intangible) dan secara totalitas lebih condong kepada kategori jasa yang tak berwujud (intangible). Menurut Burns and Holden (1989:172) produk wisata dinyatakan sebagai segala sesuatu yang dapat dijual dan diproduksi dengan menggabungkan faktor produksi, konsumen yang tertarik pada tempat-tempat yang menarik, kebudayaan asli dan festival-festival kebudayaan. 
Kotler dan Amstrong (1989:463) menterjemahkan produk wisata sebagai sesuatu yang ditawarkan kepada konsumen atau pangsa pasar untuk memuaskan kemauan dan keinginan termasuk di dalam objek fisik, layanan, SDM yang terlibat didalam organisasi dan terobosan atau ide-ide baru. Suwantoro (1997:49), berpendapat produk wisata merupakan keseluruhan pelayanan yang diperoleh dan dirasakan atau dinikmati wisatawan semenjak ia meninggalkan tempat tinggalnya, sampai ke daerah tujuan wisata yang telah dipilihnya dan kembali ke rumah dimana ia berangkat semula. Bukart dan Medlik (dalam Yoeti,2008:151) mendeskripsikan produk wisata sebagai susunan produk yang terpadu, yang terdiri dari obyek wisata, atraksi wisata, transportasi (jasa angkutan), akomodasi dan hiburan di mana tiap unsur dipersiapkan oleh masing-masing perusahaan dan ditawarkan secara terpisah.

Tabel 1. Strategi dan Penataan Ruang Kota Depok untuk Pariwisata

\begin{tabular}{|c|c|c|c|}
\hline Kecamatan & $\begin{array}{l}\text { Peruntukan } \\
\text { Alam }\end{array}$ & $\begin{array}{ll}\text { Peruntukan } & \text { pariwisata } \\
\text { Budaya } & \\
\end{array}$ & $\begin{array}{ll}\text { Peruntukan } & \text { Pariwisata } \\
\text { Buatan } & \\
\end{array}$ \\
\hline Pancoran Mas & Situ Rawa Besar & $\begin{array}{l}\text { Kawasan Heritage Depok } \\
\text { Lama }\end{array}$ & ITC Depok \\
\hline & Taman Hutan Raya & - & - \\
\hline & Situ Asih pulo & - & - \\
\hline Cipayung & Situ Citayam & - & - \\
\hline Cilodong & Situ Cilodong & - & - \\
\hline Sukmajaya & - & - & $\begin{array}{l}\text { Kawasan Studio alam } \\
\text { TVRI }\end{array}$ \\
\hline Kecamatan Beji & $\begin{array}{l}\text { Hutan Kota Universitas } \\
\text { Indonesia }\end{array}$ & $\begin{array}{l}\text { Kawasan Seni } \\
\text { Budaya Kukusan }\end{array}$ & $\begin{array}{l}\text { Margo City di jalan } \\
\text { margonda } \\
\text { Depok Town Square di } \\
\text { jalan margonda }\end{array}$ \\
\hline Kecamatan Limo & - & - & Masjid Kubah Emas \\
\hline Kecamatan Cimanggis & - & - & Taman Wiladatika \\
\hline Kecamatan Sawangan & $\begin{array}{l}\text { Situ Pengasinan } \\
-\end{array}$ & $\begin{array}{l}- \\
-\end{array}$ & $\begin{array}{l}\text { Padang Golf } \\
\text { Wisata Agro Belimbing } \\
\text { dan Taman Hias }\end{array}$ \\
\hline
\end{tabular}

Sumber : Perda Kota Depok nomor 01 tahun 2015 tentang rencana tata ruang wilayah kota Depok tahun 2012-2023

Pembangunan pariwisata kota Depok yang diarahkan untuk pengembangan daya tarik wisata buatan terdapat di kecamatan Pancoran Mas, Sukmajaya, Beji, Limo, cimanggis dan sawangan.

\section{Gambaran Umum Kota Depok dan wisata Religi Meruyung}

Kota Depok Memiliki 10 destinasi wisata (Depok.go.id) yang dapat dikunjungi oleh masyarakat, tempat wisata yang dapat dikunjungi diantaranya:

1. Tempat Wisata Alam Kampung 99 Pepohonan, Jalan KH. Muhasan II, Kelurahan Meruyung, Kecamatan Limo, Depok, Telp. 0812-19605001, www.kampung99pepohonan.com

2. Tempat Wisata Religi Masjid Kubah Emas, Jln Raya Meruyung, Limo, Depok

3. Taman Wisata Keluarga Pasir Putih, Jl. Raya Pasir Putih, Sawangan, Depok (021) 29434479, www.tamanwisatapasirputih.com

4. Objek Wisata Anak dan Keluarga Godong Ijo, Jl. Cinangka Raya KM 10 No. 60 Serua Bojongsari, Sawangan Depok, Jawa Barat 16517 (021) 74710678, www.godongijo.com

5. Objek Wisata Seru Pondok Zidane Depok, Jl. Rawa Bengkok RT 03/04 Kampung Prigi, Bedahan, Sawangan, Depok (021) 99143564, www.pondokzidane.com

6. Liburan Asik Agrowisata Belimbing Dewa Depok kelurahan Pasir Putih, Sawangan,Depok. 
7. Tempat Wisata Studio Alam TVRI Depok, Jl. Raden Saleh No.90, Kampung Cikumpa, Kecamatan Sukmajaya, Jawa Barat, Telepon:(021) 5704720

8. Liburan Seru D'kandang Amazing Farm Depok Sawangan Depok Jawa Barat. (021) 77889007, www.dkandang.com

9. Liburan Setu Pengasinan Depok, Jalan Utomo No. 19-22, Kelurahan Pengasinan, Kec. Sawangan, Depok.

10. Cagar Alam Kota Depok Pancoran Mas, Jl. Cagar Alam Raya, Kel. Pancoran Mas, Kec.Pancoran Mas

Destinasi wisata dikota Depok bervariasi seperti wisata alam, wisata keluarga, agrowisata, wisata anak, cagar alam bahkan sampai wisata religi. Wisata religi yang dimiliki Kota Depok adalah sebuah Masjid dengan ciri khas istimewa yaitu memiliki kubah berlapiskan emas.

Masjid ini dibangun oleh $\mathrm{Hj}$. Dian Djuriah Maimun Al Rasyid, pengusaha asal Banten. Masjid berlokasi di Jalan Meruyung, Kelurahan Limo, Kecamatan Cinere danmulai dibangun sejak tahun 2001 hingga selesai sekitar akhir tahun 2006. Masjid Kubah Emas

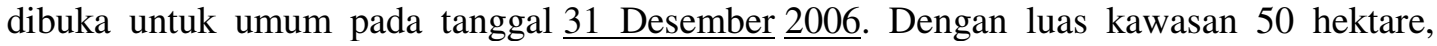
bangunan masjid menempati luas area sebesar 60 x 120 meter atau sekitar 8000 meter persegi. Masjid kubah emas dapat menampung sekitar kurang lebih 20.000 jemaah. Kawasan masjid ini sering disebut sebagai kawasan masjid termegah di Asia Tenggara.

Masjid Dian Al Mahri memiliki 5 kubah. Satu kubah utama dan 4 kubah kecil. Uniknya, seluruh kubah dilapisi emas setebal 2 sampai 3 milimeter dan mozaik kristal. Bentuk kubah utama menyerupai kubah Taj Mahal. Selain itu, relief hiasan di atas tempat imam juga terbuat dari emas 18 karat. Begitu juga pagar di lantai dua dan hiasan kaligrafi di langitlangit masjid.

Sedangkan mahkota pilar masjid yang berjumlah 168 buah berlapis bahan prado atau sisa emas. Ciri lainnya adalah gerbang masuk berupa portal dan hiasan geometris serta obelisk sebagai ornamen. Enam menara (minaret) berbentuk segi enam atau heksagonal, yang melambangkan rukun iman, menjulang setinggi 40 meter. Pada puncaknya terdapat kubah berlapis mozaik emas 24 karat. Sedangkan kubahnya mengacu pada bentuk kubah yang banyak digunakan masjid-masjid di Persia dan India. Lima kubah melambangkan rukun Islam, seluruhnya dibalut mozaik berlapis emas 24 karat yang materialnya diimpor dari Italia.Pada bagian interiornya, masjid ini menghadirkan pilar-pilar kokoh yang menjulang tinggi guna menciptakan skala ruang yang agung. (Depok.go.id)

\section{Metodologi Penelitian}

Metode penelitian menjelaskan rancangan kegiatan, ruang lingkup atau objek, bahan dan alat utama, tempat, teknik pengumpulan data, dan teknik analisis penelitian. Metode penelitian menggunakan pendekatan kualitatif. Pemilihan sampel menggunakan snowball sampling dimana lurah meruyung menjadi sumber utama. Penelitian dilakukan di kelurahan Meruyung, Kecamatan Limo. Sampel diambil dari masyarakat di kelurahan meruyung dimulai dari lurah sebagai kepala pemerintahan setempat. teknik pengumpulan data menggunakan kepustakaan, existing statistic, wawancara dan kuesioner. (1) Studi kepustakaan, meliputi buku, jurnal, artikel dan lain-lain yang bertujuan untuk mengkaji dan mengumpulkan teori yang diperlukan untuk mendukung penelitian. (2) Existing Statistic mengambil data sekunder berupa laporan resmi dari pemerintah daerah kotaDepoksuku dinas Pariwisata dan Olahraga (3) Melakukan wawancara kepadamasyarakat dengan didahului pengisian kuesioner sebagai pedoman dalam mengumpulkan informasi. Responden dimulai dari lurah meruyung, masyarakat dan pedagang yang berdomisili dikawasan wisata buatan masjid kubah emas dan kampung 99. Dalam menganalisis data diperlukan metode yang tepat, peneliti menggunakan pendekatan grounded teori. 


\section{Hasil dan Pembahasan}

Kelurahan Meruyung memiliki wisata buatan sebanyak 2 lokasi yaitu Masjid kubah emas Dian Al-Mahri dan kampung 99. Kawasan Masjid kubah emas terdiri atas beberapa bangunan yaitu Masjid kubah emas, Kantor Pengelola, Bangunan Ruko yang dipergunakan untuk Restoran, Cafetaria, Boutique dan penjualan souvenir, gedung penginapan dan aula, gedung aula utama, lahan parkir dengan aula, toilet wanita dan pria yang terpisah bangunan, loker penyimpanan alas kaki (sandal dan sepatu) serta taman.

Kawasan wisata kampung 99 adalah tempat hunian sekaligus wisata bagi keluarga, dibangun dgn konsep yang menyatu dengan alam, lokasi $14 \mathrm{~km}$ dari tol Fatmawati dengan alamat lengkap, Jl. KH. Muhasan II, Kelurahan Meruyung, Kecamatan Limo, Depok 16515 (seberang Mesjid Kubah Emas Dian Al Mahri), Telp : 0217788 3623.Ada binatang Rusa jenis Timorensis, Kambing Etawa, Sapi, Kerbau, tupai, burung, ayam mutiara.. Beragam macam pohon pun ada, seperti Pohon Maja, Trembesi, Jati Putih, Rengas, Mahoni, Kemang, Karet,dan masih banyak pohon-pohon langka lainnya, karena hampir setiap hari selalu ada pohon yg ditanami.

Ada juga pengobatan alternatif dengan terapi sengat lebah. Disini kami pun memproduksi yoghurt, buah (sukun, kiwi, orange, strawberry, anggur), carcade (teh arab), susu kambing jahe. Menu makanan dan minuman yg dijual sifatnya alami dan hasil dari kebun sendiri. Memasak pun memanfaatkan bahan yang ada seperti kayu bakar, tanpa perlu pusing menghadapi minyak tanah yang langka atau melambungnya harga gas elpiji.Bagi rekan2 yang mau mengadakan acara khusus untuk keluarga, seperti outbound untuk anak atau dewasa, arisan, family gathering, ulang tahun, menginap di rumah kayu, memancing, atau hanya untuk menikmati udara yang segar tanpa terganggu oleh bisingnya suara kendaraan, polusi asap kendaraan, makan makanan sehat di resto alam Kampung 99 Pepohonan.

\section{Masjid Kubah Emas sebagai potensi wisata religi}

Keberadaan masjid kubah emas sebagai lokasi wisata buatan bernuansa religi di kota Depok,. Wisata religi dapat diartikan sebagai kegiatan berkunjung ketempat-tempat yang memiliki makna khusus secara keagamaan. Wisata religi dilakukan guna mengambil ibrah atau pelajaran dari ciptaan Tuhan untuk menumbuhkan keimanan dan guna mengingatkan manusia bahwa tidak ada yang kekal didunia. Masjid merupakan pusat keagamaan bagi umat muslim dipergunakan untuk beribadah, sholat, i'tikaf, adzan dan iqomah. Keberadaan masjid sebagai lokasi wisata religi merupakan nilai tambah yang dapat dirasakan oleh masyarakat. Pemberitaan mengenai masjid kubah emas sebagai salah satu tempat wisata religi yang dapat dikunjungi sangatlah sedikit. Belum digerakannya peran komunitas (pengajian warga) guna memperkenalkan wisata religi, menjadi potensi yang belum tersentuh sehingga perlu untuk direncanakan kembali bagaimana potensi-potensi yang dimiliki Masjid kubah emas dapat dikembangkan untuk memperkenalkan masjid kubah emas sebagai salah satu lokasi wisata di kota Depok, khususnya dalam hal wisata religi. Berikut merupakan hasil kuesioner yang diberikan kepada sampel mengenai potensi masjid kubah emas menjadi wisata religi :

Tabel 2. contoh tabulasi jawaban kuesioner

\begin{tabular}{llcccc}
\hline No & \multicolumn{1}{c}{ Pernyataan } & SS & S & TS & STS \\
\hline 1 & $\begin{array}{l}\text { Masjid Kubah Emas bisa dikatakan } \\
\text { sebagai tempat wisata }\end{array}$ & 18 & 80 & 2 & 0 \\
2 & $\begin{array}{l}\text { Keberadaan Masjid diterima masyarakat } \\
\text { sebagai tempat wisata }\end{array}$ & 12 & 85 & 3 & 0 \\
3 & $\begin{array}{l}\text { Wisata Masjid kubah emas didatangi } \\
\text { sepanjang tahun }\end{array}$ & 12 & 68 & 20 & 0 \\
\hline
\end{tabular}

Sumber : Diolah peneliti.2017 
Hasil penelitian menunjukan bahwa pengunjung dan masyarakat setuju untuk mengatakan masjid kubah emas sebagai tempat wisata terlihat dari persentase jawaban untuk pernyataan nomor 1 bahwa 98\% (18\% sangat setuju dan $80 \%$ setuju) masyarakat diperkuat dengan pernyataan nomor 2 dimana 97\% (12\% sangat setuju dan 85\% setuju) masyarakat telah merasakan keberadaan masjid kubah emas sebagai tempat yang dikunjungi ketika memiliki waktu dan tempat guna menyegarkan pikiran.

\section{Pengaruh Pengelolaan Wisata Dalam Perekonomian}

Keberadaan masjid kubah emas memiliki dampak ekonomi terhadap masyarakat sekitar, diantaranya peluang usaha dan pekerjaan bagi masyarakat.peluang pekerjaan yang dirasakan oleh masyarakat yaitu dengan dipekerjakannya masyarakat sekitar oleh pihak yayasan dalam pengelolaan dan perawatan masjid. Dengan memiliki pekerjaan tetap, keadaan ekonomi keluarga pekerja akan stabil sehingga mereka dapat memiliki kehidupan yang lebih baik dari upah yang mereka terima.

Keberadaan masjid kubah emas membantu masyarakat dalam mendapat pekerjaan, namun bagi mereka yang ingin memulai usaha baru, ternyata tidak memiliki kesempatan yang sama. Ketika awal pembukaan masjid bagi khalayak ramai, pihak pengelola mengizikan para penjual makan, minuman dan souvenir untuk berjualan didalam kawasan masjid, namun ternyata berdampak kepada kebersihan, dampak yang ditimbulakan kurang baik dirasakan mengingat lokasi ini merupakan tempat untuk beribadah, seperti yang dikatakan bapak Juki, warga setempat " waktu dibuka pertama memang pedagang boleh masuk, tapi sampah dari jualan mereka tidak dibersihkan oleh pedagang jadinya masjid terlihat kotor, makanya pengelola sekarang melarang penjual untuk masuk kekawasan masjid lagi”.

Hal ini terlihat pada gambar 2 yaitu hasil kuesioner yang diberikan kepada pedagang lokal mengenai kesempatan yang diberikan pihak pengelola kepada pedagang lokal untuk dapat berjualan dikawasan masjid kubah emas. Sebanyak 51\% pedagang tidak setuju bahwa mereka telah diberikan kesempatan untuk berjualan, namun $45 \%$ pedagang merasa setuju bahwa mereka diberikan kesempatan untuk berjualan. Perbedaan pendapat ini dapat dipahami, karena berdasarkan pengamatan peneliti, tepat disamping pagar dan dinding kawasan masjid kubah emas, banyak pedagang yang merasakan dampak langsung pendapatan meningkat dengan adanya pengunjung yang membeli barang dagangan mereka dan terbatasnya jumlah warung dan toko yang tersedia menyebabkan banyak pedagang yang tidak bisa berdagang disana.

\section{Masjid kubah emas memberikan tempat kepada masyarakat untuk berjualan}

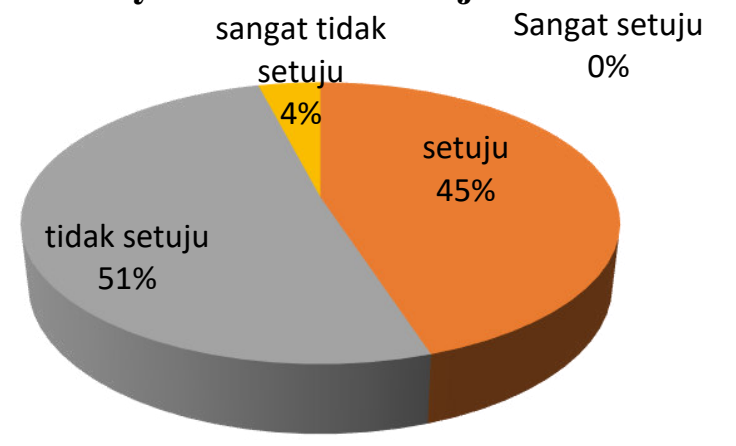

Gambar 1. Kuesioner Pedagang Pernyataan no.4 
Hasil kuesioner yang diberikan kepada pengunjung menunjukan hal yang berbeda, dikarenakan pengunjung melihat bahwa terdapat tempat yang bisa dipergunakan masyarakat untuk berjualan yaitu Ruko yang ada didalam kawasan masjid.

Masjid kubah emas memberikan tempat kepada masyarakat untuk berjualan

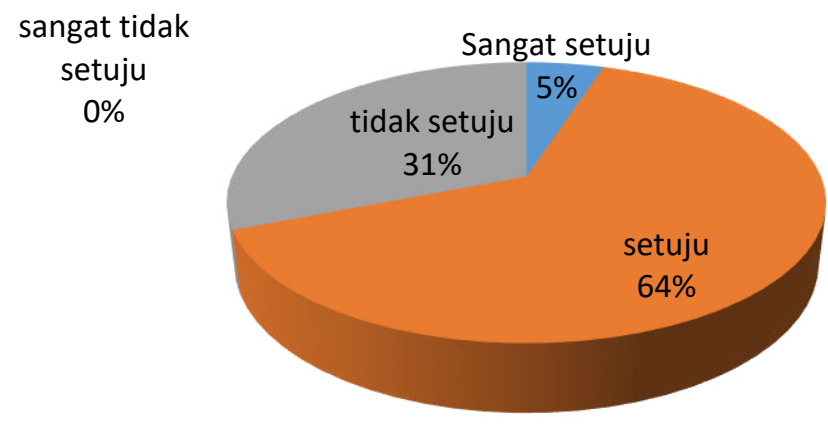

\section{Gambar 2. Kuesioner Pengunjung Pernyataan no.4}

Pengunjung tidak mengetahui bahwa ruko yang berada didalam kawasan masjid kubah emas bukanlah milik pedagang dari kalangan masyarakat sekitar, namun dikelola langsung oleh pengelola. Namun demikian pengunjung merasakan adanya tempat berdagang yang tersedia mengindikasikan bahwa pengelola mengusahakan untuk menyediakan kesempatan bagi masyarakat untuk berjualan.

Berikut akan disajikan hasil kuesioner mengenai perekonomian, kuesioner diberikan kepada sampel dari kalangan pengunjung dan pedagang:

Tabel 3. tabulasi jawaban kuesioner ekonomi

\begin{tabular}{|c|c|c|c|c|c|c|c|c|c|}
\hline \multirow[t]{2}{*}{ No } & \multirow[t]{2}{*}{ Pernyataan } & \multicolumn{4}{|c|}{ Pengunjung (\%) } & \multicolumn{4}{|c|}{ Pedagang (\%) } \\
\hline & & SS & $\mathrm{S}$ & TS & STS & SS & $\mathrm{S}$ & TS & STS \\
\hline 15 & $\begin{array}{l}\text { Masyarakat mendapatkan penghasilan } \\
\text { tambahan dengan adanya wisata } \\
\text { Masjid kubah emas. }\end{array}$ & 21 & 75 & 3 & 1 & 1 & 78 & 21 & 0 \\
\hline 16 & $\begin{array}{l}\text { Adanya wisata Masjid kubah emas } \\
\text { membuka kesempatan kerja bagi } \\
\text { masyarakat }\end{array}$ & 21 & 75 & 4 & 0 & 2 & 77 & 19 & 2 \\
\hline 20 & $\begin{array}{l}\text { Adanya wisata Masjid kubah emas, } \\
\text { membantu masyarakat untuk usaha } \\
\text { dibidang jasa angkutan }\end{array}$ & 5 & 89 & 6 & 0 & 4 & 69 & 22 & 5 \\
\hline 21 & $\begin{array}{l}\text { Adanya wisata Masjid kubah emas, } \\
\text { membantu masyarakat untuk usaha } \\
\text { pembuatan souvenir }\end{array}$ & 3 & 81 & 16 & 0 & 2 & 88 & 8 & 2 \\
\hline 23 & $\begin{array}{l}\text { Adanya wisata Masjid kubah emas, } \\
\text { mendatangkan banyak wisatawan yang } \\
\text { akan berbelanja }\end{array}$ & 4 & 51 & 42 & 3 & 0 & 46 & 46 & 8 \\
\hline 24 & $\begin{array}{l}\text { Adanya wisata Masjid kubah emas, } \\
\text { membuat jasa angkutan umum } \\
\text { bertambah banyak }\end{array}$ & 1 & 28 & 55 & 16 & 0 & 31 & 50 & 19 \\
\hline 25 & $\begin{array}{l}\text { Adanya wisata Masjid kubah emas, } \\
\text { meningkatkan pendapatan masyarakat } \\
\text { sekitar }\end{array}$ & 23 & 76 & 1 & 0 & 0 & 89 & 11 & 0 \\
\hline
\end{tabular}

\section{Pengaruh Pengelolaan Wisata Dalam Sosial Budaya}

Objek wisata religi masjid kubah emas merupakan objek wisata yang telah lama dikenal oleh masyarakat. Dengan adanya masjid kubah emas menciptakan lapangan pekerjaan bagi 
masyarakat sekitar sebagai tenaga pekerja didalam masjid kubah emas yang berarti meningkatkan pendapatan keluarga pekerja. Pengaruh yang dirasakan oleh masyarakat sekitar dari keberadaan masjid kubah emas diantaranya : (1) Mengubah status sosial masyarakat yang tadinya pengangguran menjadi tidak pengangguran lagi (punya pekerjaan) (2) Membuka peluang usaha, penduduk memiliki usaha seperti minuman (es kelapa, kopi, teh,,dll) dan makanan ( gorengan, mie ayam,dll), buah-buahan, bengkel sepeda motor, aneka asesoris dan souvenir tempat wisata. (3) Tingkat pendidikan semakin membaik. Dengan memiliki pekerjaan maka pendapatan rumah tangga akan meningkat yang artinya kesempatan untuk membiayai sekolah anak ke jenjang yang lebih tinggi semakin terbuka. (4) Menambah keimanan masyarakat dan pengunjung yang datang, yaitu dengan adanya acara rutin pengajian dilingkungan masjid kubah emas.

Pengaruh sosial yang dirasakan masyarakat serupa dengan pernyataan Jamieson, Goodwin and Edmuns (2004) bahwa: tourismhave impact positively on the lives of poor people and which enable them to rise out of poverty.

Tabel 4. Tabulasi jawaban kuesioner sosial budaya

\begin{tabular}{|c|c|c|c|c|c|c|c|c|c|}
\hline \multirow[t]{2}{*}{ No } & \multirow[t]{2}{*}{ Pernyataan } & \multicolumn{4}{|c|}{ Pengunjung (\%) } & \multicolumn{4}{|c|}{ Masyarakat (\%) } \\
\hline & & SS & $\mathrm{S}$ & TS & STS & SS & $\mathrm{S}$ & $\mathrm{TS}$ & STS \\
\hline 17 & $\begin{array}{l}\text { Adanya wisata Masjid kubah emas } \\
\text { menjadi kesempatan untuk memulai } \\
\text { usaha / berdagang }\end{array}$ & 20 & 70 & 10 & 0 & 5 & 90 & 5 & 0 \\
\hline 18 & $\begin{array}{l}\text { Sebelum ada wisata Masjid kubah } \\
\text { emas, masyarakat mencari pekerjaan } \\
\text { keluar kawasan (kecamatan/kota) }\end{array}$ & 16 & 72 & 11 & 1 & 3 & 90 & 7 & 0 \\
\hline 19 & $\begin{array}{l}\text { Adanya wisata Masjid kubah emas, } \\
\text { membantu masyarakat untuk } \\
\text { menyekolahkan anak-anak }\end{array}$ & 7 & 87 & 6 & 0 & 2 & 90 & 6 & 2 \\
\hline 22 & $\begin{array}{l}\text { Adanya wisata Masjid kubah emas, } \\
\text { membuat orang luar daerah datang } \\
\text { untuk membuka usaha }\end{array}$ & 1 & 24 & 58 & 17 & 0 & 41 & 43 & 16 \\
\hline
\end{tabular}

Hambatan dan kendala pengembangan Masjid kubah emas sebagai wisata religi

\section{Pembangunan Sarana dan prasarana usaha}

Sarana dan prasarana usaha sangatlah penting guna mendukung keberadaan masjid kubah emas sebagai wisata religi. Sebagai contoh, belum adanya pusat oleh-oleh dan souvenir wisata religi msajid kubah emas selain daripada yang dikelola langsung oleh pihak yayasan Dian Al-Mahri didalam kawasan masjid kubah emas.

Akses jalan menuju Masjid kubah emas tergolong sulit. Untuk mencapai lokasi, pengunjung dengan kendaraan umum, perlu menggunakan angkutan umum sebanyak 2 kali dimulai dari terminal Depok kemudian dilanjutkan dengan menggunakan ojek untuk sampai ke masjid. Hal ini akan menyulitkan bagi mereka yang tidak memiliki kendaraan pribadi untuk berkunjung ke masjid kubah emas.

\section{Pemasaran Masjid kubah emas sebagai wisata religi}

Masjid kubah emas dimiliki dan dikelola secara perseorangan dengan tujuan utama sebagai tempat ibadah. Pihak pengelola tidak melakukan pemasaran mengenai keberadaan masjid kubah emas sebagai wisata religi, karena memang hal tersebut bukanlah tujuan utama didirikannya masjid ini, sehingga informasi mengenai masjid kubah emas diperoleh dari orang ke orang atau dari teman dan keluarga secara langsung.

Pihak pemerintah daerah belum bisa mempublikasikan masjid kubah emas sebagai wisata religi karena pengelolan masjid yang dimiliki perseorangan dan tidak bersifat 
komersil. Seluruh acara yang diadakan oleh pihak pengelola, dilakukan dan dipublikasikan secara langsung oleh pihak yayasan Dian Al-Mahri.

\section{Hubungan Pemerintah daerah-pengelola}

Hasil pengamatan dan wawancara, terlihat bahwa pemerintah daerah terus berupaya untuk melakukan pembicaraan mengenai penglolaan kawasan masjid kubah emas untuk dijadikan kawasan wisata religi kotaDepok yang dikelola bersama antara pihak yayasan Dian Al-Mahri dan pemerintah daerah.

Tabel 5. Tabulasi jawaban kuesioner sarana prasarana

\begin{tabular}{|c|c|c|c|c|c|c|c|c|c|}
\hline \multirow[t]{2}{*}{ No } & \multirow[t]{2}{*}{ Pernyataan } & \multicolumn{4}{|c|}{ Pengunjung (\%) } & \multicolumn{4}{|c|}{ Masyarakat (\%) } \\
\hline & & SS & $\mathrm{S}$ & TS & STS & SS & $\mathrm{S}$ & $\mathrm{TS}$ & STS \\
\hline 6 & $\begin{array}{l}\text { Jalan ke Masjid kubah emas mudah } \\
\text { dilalui kendaraan }\end{array}$ & 23 & 71 & 6 & 0 & 9 & 36 & 31 & 24 \\
\hline 7 & $\begin{array}{l}\text { Tersedianya angkutan umum menuju } \\
\text { Masjid kubah emas }\end{array}$ & 22 & 73 & 5 & 0 & 8 & 60 & 19 & 13 \\
\hline 8 & $\begin{array}{l}\text { Lokasi wisata Masjid kubah emas } \\
\text { tersedia tempat makan }\end{array}$ & 14 & 59 & 26 & 1 & 6 & 88 & 6 & 0 \\
\hline 9 & $\begin{array}{l}\text { Lokasi wisata Masjid kubah emas } \\
\text { tersedia tempat parker }\end{array}$ & 17 & 67 & 15 & 1 & 7 & 93 & 0 & 0 \\
\hline 10 & $\begin{array}{l}\text { Lokasi wisata Masjid kubah emas } \\
\text { tersedia penginapan }\end{array}$ & 13 & 39 & 41 & 7 & 2 & 69 & 25 & 4 \\
\hline
\end{tabular}

\section{Simpulan dan Saran \\ Simpulan}

Keberadaan masjid sebagai lokasi wisata religi merupakan nilai tambah yang dapat dirasakan oleh pengunjung ketika mengunjunginya. Sebagai sebuah lokasi wisata para wisatawan datang dengan alasan yang berbeda diantaranya 1) ingin melihat langsung masjid dengan kubah yang berlapis emas 2) niat beribadah, 3) Berwisata ,4) melihat arsitektur masjid.

Pengunjung dan masyarakat setuju untuk mengatakan masjid kubah emas sebagai tempat wisata terlihat dari persentase jawaban untuk pernyataan nomor 1 bahwa $98 \%$ (18\% sangat setuju dan $80 \%$ setuju) masyarakat diperkuat dengan pernyataan nomor 2 dimana 97\% (12\% sangat setuju dan $85 \%$ setuju) masyarakat telah merasakan keberadaan masjid kubah emas sebagai tempat yang dikunjungi ketika memiliki waktu dan tempat guna menyegarkan pikiran.

\section{Saran}

Hasil kuesioner yang diberikan kepada pedagang lokal mengenai kesempatan yang diberikan pihak pengelola kepada pedagang lokal untuk dapat berjualan dikawasan masjid kubah emas. Sebanyak $51 \%$ pedagang tidak setuju bahwa mereka telah diberikan kesempatan untuk berjualan, namun $45 \%$ pedagang merasa setuju bahwa mereka diberikan kesempatan untuk berjualan.

\section{Daftar Pustaka}

Azwar, Saifuddin. (1999). Reliabilitas dan validitas:Seri pengukuran Psikologi.Yogyakarta:Sigma Alpha.

Chaplin, J. P. (1999). Kamus Lengkap Psikologi.penerjemah : Kartini Kartono.

Damanik, J., (2009)“ Isu-Isu Krusial Dalam Pengelolaan Desa Wisata Dewasa Ini “, Jurnal Kepariwisataan Indonesia 5(3) : 127-137

Herawati, T.(2011). Model pemberdayaan Masyarakat Desa dan Penanggulangan kemiskinan melalui pengembangan desa wisata di depok. Jurnal ekonomi Bisnis : vol 10 no 2. Jakarta 
Meijerink, G \& P. Roza (2007). The role of agriculture in development. Markets, Chains and Sustainable Development Strategy and Policy Paper, no 5. Stichting DLO: Wageningen

Murdiyanto E.(2011). Partisipasi masyarakat dalam pengembangan desa wisata Karanggeneng, purwobinangun, pakem, Sleman. Jurnalpariwisata: vol 7 No 2 UNS. Yogyakarta.

Nasikun. (1997). Model Pariwisata pedesaan : pemodelan Pariwisata untuk pembangunan Pedesaan yang berkelanjutan. Dalam Prosiding pelatihan dan Lokakarya perencanaan pariwisata berkelanjutan .Bandung : Institut Teknologi Bandung.

Prasetyo, Bambang dan Lina M. Jannah (2005). Metode Penelitian Kuantitatif: Teori dan Aplikasi. Jakarta : PT. Raja Grafindo Persada

Raharjana, DT.(2012). Membangun Pariwisata Bersama Rakyat: Kajian pariwisata Lokal dalam membangung desa Wisata di Dieng plateau. Jurnal Kawistara: vol 2 No 3. Universitas Gadjah Mada . Yogyakarta

Sarwono, Sarlito W (1999). Psikologi Sosial : Individu dan Teori-Teori Psikologi Sosial. Edisi 3. Jakarta: Balai Pustaka.

Syahza, A.(2004). Pemberdayaan Ekonomi Masyarakat Pedesaan Melalui Pengembangan Industry Hilir Berbasis Kelapa Sawit Di Daerah Riau. Jurnal Sosiohumaniora, Vol 6 No.3. Lemabaga Penelitian Universitas Padjajaran: Bandung.

Undang-Undang Republik Indonesia No 10 tahun 2009 tentang Kepariwisataan.

World Tourism Organization .(2000). WTO News Issue 2. Madrid

Yoeti,Okta.(2008). Perencanaan Strategis Pemasaran daerah Tujuan Wisata,Jakarta: PT Pradnya Paramita 